\title{
THE EXECUTIVE BODIES AS SUBJECTS OF PUBLIC ADMINISTRATION: CONCEPTS, SIGNS, TYPES AND THEIR REFORMING
}

Hnatovska A. I.

\section{INTRODUCTION}

The executive bodies are the main entities that implement public administration.

Executive bodies develop the main directions of state socio-economic policy, state defense, ensuring public order, organize the management of state property, carry out foreign policy and perform other functions. The quality of executive power affects the economic and political situation in the country. These authorities have broad powers: lawmaking, law applying and law enforcement.

Therefore, it is important to study the executive authorities not only as subjects of administrative law, but also as subjects of public administration. Executive power is law-based implementation of state functions by the state authorities. These are state functions in the areas of economic and cultural development, social security and health care, transport and communications, state security and protection of public order, national defense, etc. Among the bodies of state power an important place is occupied by the bodies of executive power that perform state functions in management of economic, sociocultural, administrative and political construction. Each of these bodies acts on behalf of the state, has a certain legal status and a holder of legal powers. Implementation of functions ensures the achievement of the goal of executive activity. Therefore, the executive authorities carry out public administration activities and they act equally alongside the legislative and judicial bodies.

\section{The characteristics of executive bodies as public administration subjects}

A subject of public administration is a holder of rights and duties in the sphere of public law, provided by administrative law, who is able to exercise the granted rights, and perform the assigned duties ${ }^{1}$.

In the general theoretical sense, the subject is recognized as a bearer of subject-practical activity and cognition (individual or social group), a source of activity that is aimed at the object.

${ }^{1}$ Алфьоров С.М. Адміністративне право України. Загальна частина. Київ: Центр учбової літератури, 2011. С. 218. 
It is known from the theory of law that subjects (both participants in legal relations in general and administrative relations in particular) must have legal personality.

The concept of administrative legal personality consists of the potential ability to have rights and responsibilities in the area of public administration, implement the rights and obligations provided in public administration, subjective rights and responsibilities in the area of public administration ${ }^{2}$.

In the area of public administration, subjective rights and responsibilities have both common features and features that allow them to be distinguished. They are united by a common administrative and legal nature, existence in administrative legal relations, the presence of boundaries in behavior, belonging to persons with administrative capacity

The differences are that the rights are exercised in the interests of the holder and the responsibilities are exercised in the interests of others. Such features are endowed with executive bodies.

First, they are functional-sectoral carriers of executive power in the state, and the status of the executive body is assigned to them in the normative order;

second, it is the most important component of public administration and the state apparatus as a whole;

third, they are united by a single leadership and subordination, as a result of which they act in a coordinated and purposeful manner;

fourth, each bodies of this system is endowed with specific competence in the area of public administration and the implementation of state executive power;

fifth, the system of executive bodies has a regulatory impact on all spheres of state and public life;

sixth, within their competence, the executive bodies are organizationally and functionally independent;

seventh, a specific type of state activity is carried out, which in its legal content is executive and administrative ${ }^{3}$.

In the scientific literature, there are different approaches to understanding the concept of «executive power» both in content and form. A.S. Vasiliev defines the body of state executive power as the primary element of the apparatus of public administration, which is formed by the state to carry out the tasks and

\footnotetext{
${ }^{2}$ Ківалов С.В. Адміністративне право України: навчально-методичний посібник Одеса: Юридична література, 2002. С. 64.

3 Авер'янов В.Б. Органи виконавчої влади в Україні / В.Б. Авер'янов; НАН Укр.: Ін-т держави ім. Корецького. Київ: ІнЮре, 1997. С. 34.
} 
functions of state executive power ${ }^{4}$. Some law scholars consider the executive bodies as one of the elements of the public administration system ${ }^{5}$.

According to Melnik R.S. and Bevzekno V.M. executive authorities are the main subject of public administration, which is directly authorized to comply the law. It is the implementation of these instructions and is the main task of the executive bodies ${ }^{6}$.

The Constitution of Ukraine clearly indicates the types of executive bodies. For Art. 113 the highest body in the system of executive bodies is the Cabinet of Ministers of Ukraine; Art. 114 indicates the existence of central executive bodies (ministries); Art. 118 defines local state administrations as local executive bodies ${ }^{7}$.

Bodies of executive power of Ukraine are divided into:

1) higher;

2) central;

3) local;

4) special $^{8}$.

The highest executive body is the Government of Ukraine - the Cabinet of Ministers. It is accountable to the President of Ukraine and is under the control and accountable to the Verkhovna Rada of Ukraine.

The Cabinet of Ministers resigns before the newly elected President of Ukraine.

Central are those bodies whose activities extend to the entire territory of Ukraine. The central executive bodies include those that manage the relevant industries or perform functional (intersectoral) management. These are ministries; public services; agencies; inspections; central executive bodies with a special status. The work of central executive bodies is directed and coordinated by the Cabinet of Ministers of Ukraine9.

The central executive body generalizes the practice of law application within its competence, develops proposals for improving the legislation

\footnotetext{
${ }^{4}$ Васильев А.С. Административное право Украины Харків: Одисей, 2001, С. 78.

${ }^{5}$ Нижник Н.Р. Системний підхід в організації державного управління: навчальний посібник Київ, 1998. С. 19.

${ }^{6}$ Мельник Р.С., Бевзенко В.М. Загальне адміністративне право: навчальний посібник / За заг. ред. Р.С. Мельника. Київ: Ваіте, 2014. С. 139.

${ }^{7}$ Конституція України: Закон України від 28.06.1996р. 254к/96-ВР. Відомості Верховної Ради Украӥни. 1996. № 30. Ст. 141.

8 Авер'янов В.Б. Органи виконавчої влади в Україні / В.Б. Авер'янов; НАН Укр.: Ін-т держави ім. Корецького. Київ: ІнЮре, 1997, С. 16.

${ }^{9}$ Нижник Н.Р. Системний підхід в організації державного управління: навчальний посібник Київ, 1998, С. 116.
} 
and in the prescribed manner submits them to the President of Ukraine, the Cabinet of Ministers of Ukraine. The central body of executive power within the limits of the powers on the basis and on execution of acts of the legislation issues orders, organizes and controls their execution.

Bodies of special competence are endowed with specific powers. They have a special order of creation, operation and liquidation. The activities of these bodies are regulated by a specially created law.

Local public authorities extend their activities to a specific administrativeterritorial unit. They perform the powers of central executive bodies in the district, region, city.

The system of local executive bodies consists of region, Kyiv and Sevastopol city state administrations, as well as their respective district and rayon state administrations in the cities of Kyiv and Sevastopol. In powers implementation local state administrations are guided by the laws of Ukraine, acts of the President of Ukraine, the Cabinet of Ministers of Ukraine, and executive bodies of the highest level.

Executive bodies are the largest group of state bodies. They interact with other government bodies, local governments and citizens' associations.

State powers are expressed in the competence of executive bodies and are practically realized in the decisions made by them. They are drawn up in the form of legally binding regulations and individual legal acts issued by them on behalf of the state, as well as reflected in specific actions and measures taken. In order to implement the adopted decisions, the executive authorities exercise control and supervision over the strict observance of the requirements contained in the management acts. At the same time, they rely on the intellectual, organizational, material and coercive power of the state. They protect these requirements from violations by applying a variety of measures of education, persuasion, explanation and encouragement, and, if necessary, state coercion. The main purpose of the executive branch is due to its social purpose and special position in the system of separation of powers - high-quality implementation of public administration.

The essence of the functions of the executive power is revealed during the analysis of its results, which are achieved in the process of exercising this power ${ }^{10}$.

For the better studing the peculiarities of the executive bodies determine their characteristics. Scientists identify various features of the executive branch.

\footnotetext{
10 Державне управління: теорія і практика за заг. ред. В.Б. Авер'янова, Київ: Юрінком Інтер, 1998. C. 209.
} 
Yu.P. Bityak indicates the following characteristics of executive power:

1) an independent branch of state power in Ukraine;

2) is independent only in connection with the practical implementation of the Constitution and laws of Ukraine;

3) it has a state-legal nature;

4) endowed with power to influence the behavior and activities of people and their associations;

5) the executive power cannot be identified with the executive activity, as such activity is a form of implementation of the executive power;

6) executive power is exercised by a system of specially created entities ${ }^{11}$.

S.P. Kisil to the features of executive power includes:

1) the organizing nature of the executive branch. The organizational aspect of executive power is manifested in all spheres of public relations: economic, political, social, cultural, national, security, etc. The executive power directly organizes the internal law and order, defense, public and state security, performs organizational, coordination and control functions in relation to various phenomena of public life;

2) permanence (continuity) of the executive branch. That is, the executive power acts constantly and purposefully, being in constant interaction with the objects of influence, faces new social phenomena;

3) the prerogative nature of the executive branch. The emergence of new public relations not regulated by current legislation necessitates their immediate regulation by the executive authorities;

4) the universal nature of the executive branch. Executive power is exercised on the territory of the state wherever people live, where public relations arise. The boundaries of the executive branch coincide with the borders of the state. The universality of the executive power is manifested in the implementation of lawmaking through the adoption of various bylaws that clarify and detail the law;

5) the substantive nature of the executive branch, ie the presence of the executive branch of significant resources: legal, informational, economic, technical, ideological, providing organizational and managerial influence on social processes. The executive power is at the direct disposal of the armed forces, the police, and penitentiary institutions, which gives them opportunity to use the actual and legal possibilities of administrative coercion available to them;

6) the presence of a hierarchically built, clearly structured apparatus of executive power ${ }^{12}$.

\footnotetext{
${ }^{11}$ Адміністративне право України за ред. Ю.П. Битяка. Київ: Юрінком Iнтер, 2007, С. 243.

12 Кисіль С.П. Центральні органи виконавчої влади України: стан і розвиток: наукове видання. Київ, 1999. С. 7.
} 
It should be emphasized that the executive authorities are characterized by a set of all these features, their strict combination.

Thus, in terms of features, the executive branch is a personified subject of public administration, which has a clearly defined competence by law. In the implement of its powers, the executive body makes legally binding decisions and performs other legally significant actions. The activity of the executive power in its content is nothing more than the performance of general functions that arise in the process of joint work, and the method of implementation - is the power activity.

Among the subjects of public administration, the executive bodies occupy a decisive place and significantly influence the implementation of public administration in general, as they participate in all types of administrative proceedings.

Bodies of executive power - is an organized team that forms an independent part of the state apparatus, endowed with competence, performs a public function, the structure and activities of which are governed by law.

Legislatures make laws, executive bodies execute them, put them into practice.

Executive bodies, as subjects of public administration, have the right to make decisions at their discretion, but within the law, and to issue regulations, administrative acts, to conclude administrative contracts.

\section{Central executive bodies reforming}

The successful activity of the state is connected with the effective functioning of the executive power, the creation of an optimal system of its bodies that carry out public administration. Further development and reform of the current system of executive bodies in Ukraine should ensure the effectiveness of the executive branch, its effective impact on the managed spheres of social development of the country ${ }^{13}$.

The most pressing scientific problem of Ukrainian state formation is to improve the organization and functioning of the executive bodies.

It is generally accepted that the executive branch implements the most important functions of the state. Given this, the theoretical rationale for optimizing management functions - the main factor in the effective functioning of the executive branch - is important both from a theoretical and practical point of view.

13 Йосифович Д.І., Андрусишин Р.М. Проблеми реформування органів виконавчої влади в Україні. Науковий вісник Львівського державного університету внутрішніх справ 2018. № 4. C. 143. 
Improving the efficiency and effectiveness of the public administration system, clarifying the patterns of development of social processes, as well as solving problems of reforming systems (institutions) that ensure the proper level of its vital functions, is an important factor in ensuring national security.

That is why in recent decades in different countries the emphasis is on research aimed at finding new models of public administration in the context of modern globalization, taking into account the specific cultural, historical, socio-political and economic features of national development ${ }^{14}$.

The best results of the hierarchical organizational social system are usually provided under the condition of its monocentric rather than polycentric structural construction. That is, provided that all structural units of the system are subject to leadership from one, not from several centers of power. Instead, the republican form of government of the mixed, semipresidential type established by the Constitution of Ukraine is naturally connected with the so-called dualism of executive power. It means that the powers of the highest executive are to some extent divided between the President of Ukraine and the Cabinet of Ministers ${ }^{15}$.

Both domestic and foreign experience show that public administration reform should be organically integrated into the processes of social transformation aimed at the progressive development of society.

The success of Central and Eastern European countries in carrying out administrative reforms is largely due to a clear understanding of reforms not as a self-sufficient process, but as a supportive activity to create an administrative system capable of carrying out the full range of necessary social transformations ${ }^{16}$.

Based on the experience of the first years of Ukraine's independence, scholars have concluded that it is impossible to radically reform the economy without significant changes in the political sphere, especially in the field of public administration ${ }^{17}$.

\footnotetext{
14 Западинчук О.П Оптимізація центральних органів виконавчої влади в контексті проведення адміністративної реформи. URL: http://academy.gov.ua /ej/ej13/txts/Zapadynchuk.pdf (дата звернення: 31.05.2020).

15 Авер'янов В., Дерець В., Пухтецька А. Організація виконавчої влади потребує реформування. Право України. 2009. № 12. С. 40.

16 Tamara Latkovska, Lyubov Bila-Tiunova Political and economic governance: a comparative analysis of Eastern European countries and Ukraine. Baltic Journal of Economic Studies. Volume 5 Number 3. Riga: Publishing House «Baltija Publishing», 2019, P. 91-92.

17 Реформування державного управління в Україні: проблеми і перспективи / наук. кер. В.В. Цвєтков. Київ: Оріяни, 1998, С. 68.
} 
The goals, scope and sequence of steps for administrative reform should be determined by the ultimate goals and measures of economic, political and social reforms ${ }^{18}$.

Undeveloped scientific problem significantly hinders the implementation of functional and structural reforms of the executive branch, deprives political and managerial activities of the necessary organizational focus and efficiency.

One of the reasons for the delay in the reform of public administration is the lack of elaboration of certain problems, the permanent search for the optimal model of organization of the public administration system ${ }^{19}$.

The tendency to self-reproduction inherent in any bureaucratic system has caused excessive multifunctionality of the executive branch.

Insufficient distribution of functions in this system and the lack of a clear link between them often provoked an internal conflict of interest in the activities of many executive bodies, which was reflected in the excess of state control over its expediency and complexity of administrative services. The activities of these administrative structures in the field of public relations were reduced to the issuance of permits and the imposition of fines for failure to comply with established rules ${ }^{20}$.

The need to reform the executive branch arose in the twentieth century. The then existing model of executive power in Ukraine was a complex contradictory phenomenon with many bureaucratic distortions and shortcomings. The apparatus of public administration could not ensure social reforms.

Decree of the President of Ukraine «On the system of central executive bodies» ${ }^{21}$ № 1572 of 15.12 .1999 revealed the following issues:

1) determine the procedure for approval of regulations on central executive bodies, the structure and maximum number of employees of their central office, staff list and budget;

2) the Cabinet of Ministers of Ukraine has been granted the right to establish government bodies within the central executive body within the

${ }^{18}$ Гонцяж Я., Гнидюк Н. Адміністративна реформа: нездійснені мрії та втрачені можливості: Як знайти конструктивний шлях для реалізації осн. компонентів адмін. реформи? / Центр економічного розвитку. Київ: Міленіум, 2002, С. 92.

19 Адміністративна реформа в Україні: сучасний стан, проблеми та перспективи: монографія / за ред. Н.Р. Нижник та Н.Т. Гончарук. К.иїв: Моноліт, 2009. С. 8.

20 Западинчук О.П Оптимізація центральних органів виконавчої влади в контексті проведення адміністративної реформи. URL: http:/academy.gov.ua /ej/ej13/txts/Zapadynchuk.pdf (дата звернення: 31.05.2020).

${ }^{21}$ Про систему центральних органів виконавчої влади: Указ Президента України від 15 грудня 1999 року № 1572/99 URL: https://zakon.rada.gov.ua/laws/show/1572/99 (дата звернення 31.05.2020). 
funds provided for the maintenance of executive bodies. This was necessary for the management of certain subsectors or areas of activity, ensuring the implementation of control, regulatory and permitting and registration functions for individuals and legal entities;

3) the distinction between political and administrative positions has been established. The positions of Prime Minister, First Deputy Prime Minister, Deputy Prime Minister and Ministers were political.

The Decree of the President of Ukraine «On changes in the structure of

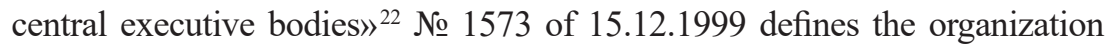
and interaction of central executive bodies, provides an exhaustive list of ministries, state committees and other central executive bodies, whose status was equated to the state committee, central executive bodies with a special status, as well as a list of central executive bodies whose activities were directed and coordinated by the Cabinet of Ministers through the relevant ministers.

According to the Resolution of the Cabinet of Ministers of Ukraine «On approval of the procedure for directing and coordinating the activities of central executive bodies through the relevant ministers» ${ }^{23}$ № 965 of 13.06.2000, the activities of the central executive body were carried out by the Minister by forming state policy executive body. This resolution determined the procedure for submitting to the government for consideration regulations developed by the central executive body and approving draft regulations of this body subject to state registration, making proposals for appointment and dismissal of heads of central executive bodies. The procedure for the exchange of information between the ministry and the central executive body was also determined, and the structure of the central executive body was approved.

The Resolution of the Cabinet of Ministers of Ukraine «On Approval of the Rules of Procedure of the Cabinet of Ministers of Ukraine»» ${ }^{24}$ № 950 of July 18, 2007 adopted the Rules of Procedure of the Cabinet of Ministers. The regulations are still valid today. Government decisions must be adopted at meetings of the Cabinet of Ministers of Ukraine, in which only

22 Про зміни у структурі центральних органів виконавчої влади: Указ Президента України від 15 грудня 1999 року № 1573/99 URL: https://zakon.rada.gov.ua/laws/show/1573/99 (дата звернення 31.05.2020).

${ }^{23}$ Про затвердження Порядку спрямування і координації діяльності центральних органів виконавчої влади через відповідних міністрів: Постанова Кабінету Міністрів України від 13 червня 2000 р. № 965 URL: https://zakon.rada.gov.ua/laws/show/965-2000-\%D0\%BF (дата звернення 31.05.2020).

${ }^{24}$ Про затвердження Регламенту Кабінету Міністрів України: Постанова Кабінету Міністрів України від 18 липня 2007 р. № 950 URL: https://zakon.rada.gov.ua/laws/show/9502007-\%D0\%BF (дата звернення 31.05.2020). 
members of the Cabinet of Ministers of Ukraine must participate. Other people may be invited to address specific issues. In general, meetings of the Cabinet of Ministers of Ukraine should be closed in order to ensure free and open discussion of issues. To consider the most important issues for society and the state, it is advisable to hold special government meetings with the participation of the President of Ukraine. The procedure for approval and approval of draft government decisions should be carried out through electronic document management, when each participant has the opportunity to submit their comments and suggestions to the draft decision and see the comments and suggestions of others ${ }^{25}$.

Prior to the administrative reform, the system of higher executive bodies included bodies of various organizational forms: ministries, state committees, state commissions, services, inspections, foundations, and administrations.

The diversity of forms of central executive bodies was not sufficiently substantiated, some bodies combined functions that were incompatible in terms of good governance (policy making, regulation, control), there were bodies that did not perform public administration functions, but had the status of higher executive bodies.

The inconsistency of the institutional structure of public administration with the level of development of public relations, the needs of citizens, business, national interests of Ukraine, the existence of unresolved conflicts of interest at the level of individual civil servants and institutions, low quality, accessibility and transparency of administrative services higher executive bodies.

The basis for improving the structure of executive bodies was the idea of reorganization of executive bodies on a functional basis and the idea of hierarchy of central executive bodies.

In accordance with the requirements set for Ukraine in the process of its accession to the EU, the most important task of administrative reform was to improve the institutional and administrative capacity of Ukraine, to reorganize the system of executive bodies.

In 2010, the Decree of the President of Ukraine «On the optimization of the system of central executive bodies» ${ }^{26}$ № 1085/2010 of 09.12.2010

\footnotetext{
25 Западинчук О.П Оптимізація центральних органів виконавчої влади в контексті проведення адміністративної реформи. URL: http:/academy.gov.ua /ej/ej13/txts/Zapadynchuk.pdf (дата звернення 31.05.2020).

${ }^{26}$ Про оптимізацію системи центральних органів виконавчої влади: Указ Президента України від 9 грудня 2010 року № 1085/2010 URL: https://zakon.rada.gov.ua/laws/ show/1085/2010 (дата звернення 31.05.2020).
} 
initiated a systemic reform of public administration and began reforming higher executive bodies.

Important legal documents of that period were: the Sustainable Development Strategy «Ukraine 2020», the State Strategy for Regional Development until 2020 and the Concept of reforming local self-government and territorial organization of power in Ukraine. These documents determined the need to reform the territorial organization of power on the basis of decentralization as a component of the new regional policy in Ukraine, its strategic objectives, priorities and conceptual principles.

The program of activities of the Cabinet of Ministers of Ukraine, approved on April 14, 2016, identified decentralization and public administration reform among the main tasks of the government, confirming the irreversibility of the course to continue the implementation of this important reform.

Carrying out administrative reform, the aim of which was to build an effective model of governance at the national and regional levels, has become one of the short-term priorities of the state. Its implementation was, among other things, to optimize the system of executive bodies.

Optimization of central executive bodies - the process of bringing them to a state that would allow them to most effectively perform their tasks, functions, including the provision of administrative services.

During the implementation of the reform of the executive branch, the reform of decentralization of power took place. It has significantly affected the executive branch.

The state policy of Ukraine in the area of local self-government is based, primarily, on the interests of residents of territorial communities and provides for drastic changes and systemic reforms, decentralisation of power - that is, transfer of a significant part of powers, resources, and responsibility from the executive branch of the government to the bodies of local self-government.

Unfortunately, certain political circumstances made it impossible for the Verkhovna Rada (Parliament) of Ukraine to introduce the amendments on decentralisation to the Constitution as submitted by the President of Ukraine.

Therefore, as of 2014, the Government started the reform within the framework of the then effective Constitution.

It was expected that 2018 will become a key year in terms of formation of the basic level of local self-government: by the end of the year, most of the local councils, which were inconsiderable in number, must had amalgamated and, consequently, became capable of taking over most of the powers, used resources properly, and bear responsibility for their acts or omissions to the residents and the state. It shouled create a steady 
foundation for taking next steps in the reform of local self-government and facilitate the accelerated reforming in the area of health care, education, social services, energy efficiency, as well as in other sectors ${ }^{27}$.

The initiated reform of the executive branch included the following components:

1) standardization and regulation. Introduction of standards of quality and accessibility of public services, introduction of procedures for control and evaluation of the activities of executive bodies, development and implementation of administrative procedures;

2) anti-corruption. It is based on the adoption of anti-corruption regulations, the introduction of anti-corruption expertise of regulations and their projects, the development of regional anti-corruption programs, detailed regulation of procedures for relations between civil servants and individuals and legal entities;

3) improving the interaction between the executive branch and society. It is envisaged to introduce mechanisms for public discussion of important decisions, interaction between the executive authorities and civil society, increasing the openness of public authorities. Participation of civil society representatives in the process of preparation and decision-making by state bodies with further monitoring ${ }^{28}$.

In 2017, the reform of the executive branch continued, but changed somewhat.

On December 27, 2017, the Cabinet of Ministers of Ukraine approved The concept of optimizing the system of central executive bodies ${ }^{29}$, which contains a general framework for reform. The Public Administration Reform Strategy of Ukraine for 2016-2020 ${ }^{30}$ identifies priority tasks for reforming ministries and other central executive bodies, namely: ensuring accountability of the executive branch system to society, its rational construction, clear division of powers and responsibilities. Since the adoption of the Strategy, the work on reforming central executive bodies has focused mainly on measures aimed at strengthening the institutional capacity of ministries to formulate

\footnotetext{
27 Загальна інформація про децентралізацію URL: https://decentralization. gov.ua/about (дата звернення 31.05.2020).

${ }^{28}$ Шевчук Б. Європейські принципи належного врядування та реформа системи органів виконавчої влади в Україні Науковий вісник, 2012, Вип. 9 «Демократичне врядування», С. 7.

${ }^{29}$ Про схвалення Концепції оптимізації системи центральних органів виконавчої влади: Розпорядження Кабінету Міністрів України від 27 грудня 2017 р. № 1013-p URL: https://zakon. rada.gov.ua/laws/show/1013-2017-\%D1\%80?lang=uk (дата звернення 31.05.2020).

30 Деякі питання реформування державного управління України: Розпорядження Кабінету Міністрів України від від 24 червня 2016 р. № 474-p URL: https://zakon.rada.gov.ua/laws/ show/474-2016-\%D1\%80\#n9 (дата звернення 31.05.2020).
} 
and coordinate public policy and deprive them of their inappropriate powers. The issue of reforming ministries is also closely linked to the Strategy's objectives of reducing the total number of central executive staff, renewing staff, in particular by selecting reform specialists, and ensuring a further competitive level of remuneration for all civil servants.

Given the above approval of this Concept, which outlines the guidelines for the organization of the system of central executive bodies, is an extremely important step in the process of implementing public administration reform.

The Concept points to the problem that ministries have untapped great potential for capacity building in public policy-making. At the same time, the activities of other central executive bodies continue to focus on the development of draft regulations instead of the quality implementation of public policy.

The effective implementation of the Cabinet of Ministers of Ukraine's domestic and foreign policy depends on the existence of a professional, accountable, controlled, effective and efficient system of central executive bodies based on the rule of law, is an important and necessary condition for sustainable economic and social development.

The purpose of reforming ministries is to strengthen the institutional capacity of ministries to formulate state policy in the areas defined by the Cabinet of Ministers of Ukraine, the implementation of which is entrusted to the Cabinet of Ministers of Ukraine by the Constitution and laws of Ukraine. This will help increase the efficiency of the entire system of central executive bodies.

Today, central executive bodies include ministries, services, agencies, inspections, commissions and central executive bodies with a special status.

One of the key stages of the reform is to enhance the capacity of ministries and turn them into analytical and authority centers that will take the lead of reform implementation and enhance the Government's activities in general.

The public administration reform shifts ministries' focus from producing regulations and managing assets to forming policies in sectors that the ministry is responsible for.

This means that the ministries' effort will be concentrated on continuous analysis of problems and search for potential solutions, formation of respective policies and assessment of potential or existing consequences of their realization. Ministries will also be monitoring dissatisfaction and evaluating stakeholders' proposed policies and possible solutions. They will be analyzing the impact of solutions already under implementation on the problem for the purposes of real-time adjustment.

Policy formation will be the key function of new structural units created in ministries - policy directorates. Newly created directorates of 
strategic planning and European integration will assume the functions of coordination, policy prioritizing, and strategizing.

This will in turn enable the Government to build a balanced hierarchy of strategic goals. The national budget will be formed in line with these goals. Three-year budget planning will provide adequate funding for the achievement of goals. Continuous monitoring and assessment of results of policies will allow their performance assessment and adjustment on the basis of existing strategic goals.

There are plans, among other things, to introduce an administrative procedure based on EU principles, improve the quality of administrative services and increase the proportion of services available electronically, and reduce the administrative burden on businesses and people.

According to the Worldwide Governance Indicators, Ukraine ranks quite low in terms of competitiveness. Its position can be improved by reducing the administrative burden of public regulation, improving the quality of administrative services, and making sure administrative action is lawful and predictable.

The reform should produce a public administration system that guarantees proper implementation of political decisions and legal rules, is transparent, predictable, and client-oriented, focused on sustainable economic growth and promotes entrepreneurship and investment. In addition, good public administration should be marked by a rational use of financial and human resources, creation of conditions for people's self-realization, and transformation of the state into an attractive and effective employer ${ }^{31}$.

Public administration reform should transform the system of central executive bodies into a managed mechanism with a clear division of powers and responsibilities, optimized in terms of content and list of public functions, number of civil servants and focused on meeting the needs of society.

It is this necessary tool that should be used for its intended purpose and in the long run. It is able to increase the efficiency of public administration and significantly reduce the use of state budget funds for the maintenance of the state apparatus.

\section{CONCLUSIONS}

Among the subjects of administrative management, the central executive bodies occupy a decisive place and significantly influence the

\footnotetext{
${ }^{31}$ Реформа державного управління URL: https://www.kmu.gov.ua/diyalnist/ reformi/ efektivne-vryaduvannya/reforma-derzhavnogo-upravlinnya (дата звернення 31.05.2020).
} 
implementation of public administration in general, as they participate in all types of administrative proceedings.

Central executive bodies are an organized collective that forms an independent part of the state apparatus, endowed with competence, performs a public function, the structure and activities of which are regulated by law. Central executive bodies, as subjects of public administration, are endowed with a wide range of powers: to adopt normative acts of management, administrative acts, to conclude administrative agreements, to exercise discretionary powers, to bring to administrative responsibility, etc. Therefore, it is extremely important at the level of the law to prescribe in detail their functions and tasks.

Analysis of the current state convincingly shows that there are not so many positive results. Unfortunately, it has not yet been possible to achieve a qualitative, effective and effective breakthrough in the functioning of the public administration system, more fully meet the needs of citizens, significantly increase their living standards.

Public administration reform should transform the system of central executive bodies into a managed mechanism with a clear division of powers and responsibilities, optimized in terms of content and list of public functions, minimum number of civil servants as free from corruption and focused on meeting the needs of society.

\section{SUMMARY}

The article is devoted to the study of the views of scientists on the definition of «executive bodies». Features of executive bodies are outlined. The opinions of scientists on the features that are inherent in the executive branch are also described. The system of executive bodies is analyzed and the peculiarity of each level of executive bodies is determined.

The article describes the stages of reforming the executive branch in independent Ukraine. The normative-legal acts that introduced the reform of executive bodies have been studied and the problems that need to be solved have been identified.

\section{REFERENCES}

1. Алфьоров С.М. Адміністративне право України. Загальна частина : Київ : Центр учбової літератури, 2011. 216 с.

2. Ківалов С.В. Адміністративне право України : навчальнометодичний посібник Одеса : Юридична література, 2002. 312 с.

3. Авер'янов В.Б. Органи виконавчої влади в Україні ; НАН Укр. : Ін-т держави ім. Корецького. Київ : ІнЮре, 1997. 48 с. 
4. Васильев А.С. Административное право Украины Харьков : Одисей, 2001. 143 с.

5. Нижник Н.Р. Системний підхід в організації державного управління : навчальний посібник Київ, 1998. 159 с.

6. Мельник Р.С., Бевзенко В.М. Загальне адміністративне право: Навчальний посібник / За заг. ред. Р.С. Мельника. Київ : Ваіте, 2014. 376 с.

7. Конституція України : Закон України від 28.06.1996р. 254к/96-ВР. Відомості Верховної Ради України. 1996. № 30. Ст. 141.

8. Державне управління: теорія і практика / за заг. ред. В.Б. Авер'янова. Київ : Юрінком Інтер, 1998. 432 с.

9. Адміністративне право України / за ред. Ю.П. Битяка. Київ : Юрінком Інтер, 2007. 544 с.

10. Кисіль С.П. Центральні органи виконавчої влади України: стан і розвиток : наукове видання. Київ, 1999. $80 \mathrm{c}$.

11. Йосифович Д.І., Андрусишин Р.М. Проблеми реформування органів виконавчої влади в Україні. Науковий вісник Львівського державного університету внутрішніх справ. 2018. № 4. С. 143-152.

12. Западинчук О.П Оптимізація центральних органів виконавчої влади в контексті проведення адміністративної реформи. URL : http:// academy.gov.ua /ej/ej13/txts/Zapadynchuk.pdf (дата звернення 31.05.2020).

13. Авер'янов В., Дерець В., Пухтецька А. Організація виконавчої влади потребує реформування Право Украӥни, 2009. № 12. С. 39-46.

14. Tamara Latkovska, Lyubov Bila-Tiunova Political and economic governance: a comparative analysis of Eastern European countries and Ukraine. Baltic Journal of Economic Studies. Volume 5 Number 3. Riga: Publishing House «Baltija Publishing». 2019. P. 91-98.

15. Реформування державного управління в Україні: проблеми і перспективи / наук. кер. В.В. Цвєтков. Київ : Оріяни, 1998. 364 с.

16. Гонцяж Я., Гнидюк Н. Адміністративна реформа: нездійснені мрії та втрачені можливості: Як знайти конструктивний шлях для реалізації осн. компонентів адмін. реформи? Центр економічного розвитку. Київ : Міленіум, 2002. 92 с.

17. Адміністративна реформа в Україні: сучасний стан, проблеми та перспективи : монографія / за ред. Н.Р. Нижник та Н.Т. Гончарук. Київ : Моноліт, 2009. 384 c.

18. Про систему центральних органів виконавчої влади : Указ Президента України від 15 грудня 1999 року № 1572/99. URL : https://zakon.rada.gov.ua/laws/show/1572/99 (дата звернення: 31.05.2020).

19. Про зміни у структурі центральних органів виконавчої влади : Указ Президента України від 15 грудня 1999 року № 1573/99. URL : https://zakon.rada.gov.ua/laws/show/1573/99 (дата звернення: 31.05.2020). 
20. Про затвердження Порядку спрямування і координації діяльності центральних органів виконавчої влади через відповідних міністрів : Постанова Кабінету Міністрів України від 13 червня 2000 р. № 965. URL : https://zakon.rada.gov.ua/laws/show/965-2000-\%D0\%BF (дата звернення: 31.05.2020).

21.Про затвердження Регламенту Кабінету Міністрів України : Постанова Кабінету Міністрів України від 18 липня 2007 р. № 950. URL : https://zakon.rada.gov.ua/laws/show/950-2007-\%D0\%BF (дата звернення: 31.05.2020).

22. Про оптимізацію системи центральних органів виконавчої влади : Указ Президента України від 9 грудня 2010 року № 1085/2010. URL : https://zakon.rada.gov.ua/laws/show/1085/2010 (дата звернення: 31.05.2020).

23. Загальна інформація про децентралізацію. URL : https:/ decentralization. gov.ua/about (дата звернення 31.05.2020).

24. Шевчук Б. Європейські принципи належного врядування та реформа системи органів виконавчої влади в Україні. Науковий вісник. 2012. Вип. 9 «Демократичне врядування». С. 1-9.

25. Про схвалення Концепції оптимізації системи центральних органів виконавчої влади : Розпорядження Кабінету Міністрів України від 27 грудня 2017 р. № 1013-p. URL : https://zakon.rada.gov.ua/laws/show/10132017-\%D1\%80?lang=uk (дата звернення 31.05.2020).

26. Деякі питання реформування державного управління України : Розпорядження Кабінету Міністрів України від від 24 червня 2016р. № 474-р URL : https://zakon.rada.gov.ua/laws/show/474-2016-\%D1\%80\#n9 (дата звернення 31.05.2020).

27. Реформа державного управління. URL : https://www.kmu.gov.ua/ diyalnist/ reformi/efektivne-vryaduvannya/reforma-derzhavnogo-upravlinnya (дата звернення 31.05.2020).

Information about author: Hnatovska A. I., Candidate of Juridical Sciences, Associate Professor, Senior Lecturer at the Departmentof Constitutional, Administrative and Finance Law Chernivtsi Law Institute of the National University "Odessa Law Academy" 7, Skovorody str., Chernivtsi, 58000, Ukraine ORCID ID: orcid.org/0000-0001-7171-3209 